\title{
Applied Discourse Markers in Casual Conversations of Male Students in Dormitory Settings and Their Pedagogical Implications for EFL: An Iranian Case Study
}

\author{
Farideh Okati \\ University of Zabol \\ Correspondence concerning this article should be addressed to Farideh Okati, English Department, \\ University of Zabol, Bonjar Ave, Zabol, Iran, 98615-538. E-mail: farideh.okati@uoz.ac.ir \\ Parviz Ghasedi \\ University of Zabol

\begin{abstract}
Correspondence concerning this article should be addressed to Parviz Ghasedi, University of Zabol, Bonjar
\end{abstract} \\ Ave, Zabol, Iran, 98615-538. E-mail: ghasedi.p.988@gmail.com
}

\begin{abstract}
This study is designed to investigate the specific discourse markers that mostly occur in casual conversations among university students who live in dormitories, and to study the amount of attention these expressions receive pedagogically in the context of improving EFL speaking skills. Regarding gender, the investigation was carried out on male students and special topics they talked about are also examined. To fulfill this objective, 6 hours and 3 minutes of casual conversations among 50 students (28 BA and $22 \mathrm{MA}$ ) located in 10 dormitory rooms ( 5 in the BA and 5 in the MA) was audio-recorded and transcribed based on Sacks, Schegloff and Jefferson's transcription system. Furthermore, a semi-structured interview was used to investigate participants' attitudes towards the degree of emphasis of EFL teachers on Discourse Markers (DMs). The data were analyzed quantitatively and qualitatively (interview transcripts). According to the findings, 70 discourse markers recurred in the students' interactions. Likewise, specific topics that received more attention in their conversations were identified. Moreover, the results of the semi-structured interview indicated that discourse markers did not receive sufficient attention in EFL settings. The findings of the current study suggest that instructors and material developers could give more specific attention to discourse markers. Explaining their roles in the production of accurate utterances or bringing samples of natural usage of discourse markers could be of great help to boost learners' oral skills in the EFL context.
\end{abstract}

Keywords: casual conversation, discourse marker, pedagogical implications, dormitory, gender

Throughout the decades, policy makers, linguists, instructors, and researchers have attempted to meet changing learner needs through new teaching methods or educational frameworks. This means that there has been a significant shift in the educational paradigm that allows learners to play more active roles in educational settings. However, most Iranian EFL learners, in spite of studying English for more than four years in high school and more than two years in university, cannot produce meaningful oral outputs. Moreover, they have only a smattering of knowledge about Discourse Markers (DMs) and do not know how to effectively implement these in class interactions or casual conversations.

Due to the fact that one of the main mediums for identity construction is in performing an accurate and 
comprehensive speech, Paltridge (2012) notes that different ways of using linguistic components during interactions demonstrate different identities. He argues that the speakers of a language usually have social identities and matching linguistic repertoires, as well as possible language varieties used while interacting in specific situations and communities. In face-to-face interactions, people not only become aware of others' intentions, feelings, desires, and requests but also convey their own wants (Yule, 2006). More interestingly, Wood (2011) asserts that men and women have different ways of receiving, interpreting, and passing on the distinctive utterances of their cocommunicators in different social contexts. Casual conversation that sets the ground to communicate casually, has been considered as a main means to represent speakers' identities while implementing specific DMs whose selective uses are the direct result of gender (Matei, 2011).

Eggins and Slade (2005, cited in Paltridge, 2012, p. 26) refer to the paradox of casual conversation and argue that casual conversation is "the type of talk in which people feel most relaxed, most spontaneous and most themselves", yet it is " a highly structured, functionally motivated, semantic activity...a critical linguistic site for the negotiation of such important dimensions of our social identity as gender, generational location,...social class membership,... and subcultural and group affiliations.”

On the other hand, DMs are linguistics devices (with or without specific literal meaning) such as interjections like oh, well, conjunctions like and, but, adverbials like anyway, prepositional phrases like after all, and lexical phrases like y'know used in oral interaction, especially in casual conversations with different degrees of formality, more casual to less casual, to highlight structural and lexical connections among utilized words (Downing, 2006, Schiffrin, 2001, Renkema, 2004). They are considered as the main tenants of oral outputs (Murar, 2008) which empower interlocutors to utilize grammatically well-formed, structurally acceptable, and semantically meaningful structures in their outputs (Wierzbicka, 2003). DMs may not have referential meanings but they can be seen as meaningful devices similar to other words and phrases. For example, among speakers who have shared prior knowledge, using the DM well is one of the strategies to signal unexpected conversational action (Johnstone, 2008, p. 242). In the study of spoken forms of discourse, Renkema (2004, p. 168) mentions that the subject of "discourse markers or pragmatic particles" is focused on, and that participants in conversations use DMs to express their attitudes and to verify given and new information.

A review of the plethora of studies that were conducted on DMs indicated that various terms were implemented instead of DMs, such as discourse operators (Redeker, 1991), discourse fillers (Watanabe, 2002), or sentence connectives (Halliday \& Hasan, 1976). DMs are defined as "textual coordinates of talk that bracket units of it" (Schiffrin; 1987, p. 31) or "linguistic items whose primary function is connective" (Hansen, 1997, p. 160). Fraser (1990, cited in Paltridge, 2012, p. 103) defines them as "items, with core meaning whose interpretation is based on linguistics and conceptual context, which signal a relationship between the segment they introduce and the prior segments". Piurko (2015) considers DMs as informative means which were used to compose and assess ideas based on the communicative goals. Rahimi and Riasati (2012) refer to them as communicative means used for arranging and negotiating significance in interaction. They add that native speakers use various DMs in casual conversation and the exclusion of DMs makes one's speech sound impolite as well as boring.

Piurko (2015) refers to items such as "oh", "well", "now", "and", "or", and "I mean" as DMs and mentioned that the frequency of occurrence of these DMs are higher in spoken than in written genre. Moreover, Paltridge (2012, p. 102) considers specific functions for each one (e.g. "oh could be used for information management, self-repair, or other-repair"). However, it is assumed that DMs have general features and functions in all languages: for instance, they are utilized by the speakers of all dialects (Yilmaz, 2004), at the start of talk as a filler, or help the interlocutor to hold the floor (Muller, 2005), pronounced with or without stress, pauses, or with phonological reduction (Zarei, 2013), used to indicate topic shifts (Brinton, 1996) or turn in conversation (Croucher, 2004).

In examining the use of DMs in different societies, Fung in his work (2011) shows that British speakers of English, for example, use DMs for the purpose of pragmatic functions, while the Hong Kong speakers of English use more limited numbers and more functional forms of DMs in their interactions. Fung and Carter (2007) believe that DMs should be paid more attention to and should be taught explicitly in great detail to FL students to help them be more prepared as capable speakers and suitably skilled users of language.

A review of related literature shows that the differences between male and female speakers are not limited to using backchannels (Maltz \& Borker, 1982), hedges (Tafaroji-Yeganeh \& Ghoreishi, 2014), or formal / informal forms (Sukegawa, 1998). Some studies indicate that the occurrence of DMs in speakers' oral or written outputs are under the direct control of gender differences, concerning selection, possibility of reoccurrence, and roles (Alami, Sabbah, \& Iranmanesh, 2012). It is worth noting that this study's point of view regarding gender is aligned with 
Paltridge's view (2012, p. 20), noting that "[g]ender... is not a result of what people (already) are but a result of, among other things, the way they talk and what they do".

Some studies address male and female differences in casual conversation, concerning ways of speaking and the implementation of specific words or DMs (Macaulay, 2002; Matei, 2011; Subon, 2013; TafarojiYeganeh \& Ghoreishi, 2014; Wood, 2011). On the other hand, analyzing male and female oral outputs separately seems also to lead to more fruitful results. However, no study has investigated the implementation of specific words and DMs and/or the tendency to talk about specific topics in specific contexts, like a university dormitory, by members of a certain gender, males or females. This study set out to fill this research gap by studying the occurrence of DMs among male students in dormitories, and providing material developers, curriculum designers, and teachers a conclusive gathering of DMs that occur mostly in casual conversations among the males, a group often neglected in scholarly books and academic contexts.

\section{Materials}

\section{Theoretical Background}

Mediation, as one of the main notions of social constructivism, connotes the fact that linguistic components (symbols, DMs, free / bound morphemes, phrases, or sentences) are utilized to intercede in one's relations with others (Vygotsky, 1978). This theory "treats interaction as a social practice that shapes and reshapes language learning (Kumaravadivelu, 2006, p. 70). Moreover, the interaction hypothesis, proposed by Long (1981), claims that effective communication and interaction among learners improves their understanding and outputs. Considering language as a suitable means to create, establish, and express individual identity, Paltridge (2012, p. 91) argues that interaction or communication is "the main way in which people come together, exchange information, negotiate, and maintain social relations".

In sum, casual conversation is a co-constructed attempt to convey intentions or indicate appreciation or to threaten under certain roles and regulation concerning what/ when/ how to state something $(\mathrm{Xu}, 2009)$. The manner of implementing linguistic components in casual conversation come under the direct effects of sociocultural factors such as age, social level, educational background, and gender (Amel-Zendedel \& Ebrahimi, 2013). Similarly, Xu (2009) regarded casual conversation as one of the main requirements of fruitful interaction and highlights the impact of gender differences, which lead to implementing different communicative strategies and manners of interaction.

\section{Male-Female Differences in Using Language}

The way of using language represents social differences (Xia, 2013) hence, men and women are not only different physically but also they are different in the style and manner of utilizinglanguage (Subon, 2013; Xia, 2013). Such differences are depicted by contrasts in pitch, intonation, vocabulary determination, body movement, paralinguistic system, hesitation, and topic (Wadhaugh, 2005; Wenjing, 2012). Some of these differences are summarized in Table 1 below, based on the conclusive review of related studies.

Table 1

Men-Women differences in using language

\begin{tabular}{|c|c|c|c|}
\hline Men & Authors & Women & Authors \\
\hline $\begin{array}{l}\text { Directive/ } \\
\text { assertive and } \\
\text { getting to } \\
\text { fundamental } \\
\text { point } \\
\text { immediately }\end{array}$ & $\begin{array}{l}\text { Haas (1979); } \\
\text { Wood (2011) }\end{array}$ & $\begin{array}{l}\text { Supportive, } \\
\text { Emotional }\end{array}$ & $\begin{array}{l}\text { Cinardo } \\
(2011) ; \\
\text { Haas (1979) }\end{array}$ \\
\hline $\begin{array}{l}\text { Less } \\
\text { grammatical, } \\
\text { More colloquial }\end{array}$ & Haas (1979) & $\begin{array}{l}\text { Formal and } \\
\text { polite }\end{array}$ & $\begin{array}{l}\text { Nasiri- } \\
\text { Kakolaki \& } \\
\text { Shahrokhi } \\
(2016)\end{array}$ \\
\hline $\begin{array}{l}\text { Prefer complex } \\
\text { and lexically } \\
\text { dense sentence } \\
\text { structures }\end{array}$ & Singh (2001) & $\begin{array}{l}\text { Reoccurrence of } \\
\text { specific lexical } \\
\text { items in their } \\
\text { outputs }\end{array}$ & $\begin{array}{l}\text { Singh } \\
(2001)\end{array}$ \\
\hline Swear more & $\begin{array}{l}\text { Boulis \& } \\
\text { Ostendorf } \\
(2005)\end{array}$ & $\begin{array}{l}\text { Use tag } \\
\text { questions more }\end{array}$ & $\begin{array}{l}\text { Singh } \\
(2001)\end{array}$ \\
\hline $\begin{array}{l}\text { Use the least } \\
\text { attention- } \\
\text { getting devices }\end{array}$ & $\begin{array}{l}\text { Broadbridge } \\
(2003)\end{array}$ & $\begin{array}{l}\text { Use the most } \\
\text { attention- } \\
\text { getting devices }\end{array}$ & $\begin{array}{l}\text { Broadbridge } \\
\text { (2003) }\end{array}$ \\
\hline $\begin{array}{l}\text { Use } \\
\text { communication } \\
\text { to build up and } \\
\text { create status }\end{array}$ & $\begin{array}{l}\text { Tannen } \\
(1984) ; \\
\text { Cinardo } \\
(2011)\end{array}$ & $\begin{array}{l}\text { Tend to know } \\
\text { about their } \\
\text { communication } \\
\text { partners }\end{array}$ & $\begin{array}{l}\text { Cinardo } \\
(2011)\end{array}$ \\
\hline $\begin{array}{l}\text { Use more } \\
\text { names in their } \\
\text { oral discourse }\end{array}$ & $\begin{array}{l}\text { Boulis \& } \\
\text { Ostendorf } \\
(2005)\end{array}$ & $\begin{array}{l}\text { Use more } \\
\text { family-relational } \\
\text { terms }\end{array}$ & $\begin{array}{l}\text { Subon } \\
\text { (2013); } \\
\text { Boulis \& } \\
\text { Ostendorf } \\
(2005)\end{array}$ \\
\hline $\begin{array}{l}\text { Use a less } \\
\text { collaborative } \\
\text { style }\end{array}$ & $\begin{array}{l}\text { Howden, } \\
(1994) ; \\
\text { Matei, } 2011\end{array}$ & $\begin{array}{l}\text { Use a more } \\
\text { collaborative } \\
\text { style }\end{array}$ & $\begin{array}{l}\text { Howden, } \\
(1994) ; \\
\text { Matei, } 2011\end{array}$ \\
\hline
\end{tabular}

Lazare (2005) notes that females use more apologetic terms. More recently, Subon (2013) conducted a conclusive study to compare men and women's linguistic features in Malaysia. The outcomes showed that men talk more, use less interrogative sentences and more fillers and affirmatives, and they essentially discussed issues related to sport matches, animosity, and getting things done while women used more amenable terms, more interrogative sentences 
and answered with humor, and they talked about home, self, feelings, and their association with others. Furthermore, the results of Attaran and MoradyMoghaddam (2013) reveal critical differences between male and female's outputs concerning the selection of conjunctions/ prepositions, mental processes, and pronouns.

In a similar study, Nasiri-Kakolaki and Shahrokhi (2016) investigate the male and female contrasts in the use of complaining strategies, claiming that gender is a crucial factor in determining the ratio of politeness. Their findings indicate that women tend to be more polite during conversations than men. In a rather different study, Khaghaninejad and Bahrani (2016) explore the impacts of gender differences on intermediate learners' speaking fluency and accuracy. The results of the data analysis show that the male speakers were more accurate while the female speakers were more fluent.

\section{Male-Female Differences in Using Discourse Markers}

Gender differences can affect the kinds, reoccurrence, and functions of DMs in casual conversation (Alami, Sabbah and Iranmanesh, 2012). Vanda and Péter (2011) investigate male and female differences in the use of DMs. Their findings show that there is no quantitative contrast between different genders in using DMs. However, whereas men use you know as a means for hesitation and topic change, women use it for seeking understanding.

Furthermore, Matei (2011) notes that the reoccurrence of DMs in women's oral productions is greater than with men. He adds that males use more discursive words instead of supportive ones, also men prefer to use you know less than women (Macaulay, 2008). Tafaroji-Yeganeh and Ghoreishi (2014) investigate a male preference to use DMs in academic writing,articles, written by non-native speakers in English. The analyses revealed that males put more emphasis on using boosters in their writing. Similarly, the results of Croucher's study (2004) make it clear that there is not a significant difference in terms of using um and $u$ h DMs between males and females. However, males used like and you know less often. Matei (2011) mentions that casual conversation provides the appropriate setting for representing structural and functional aspects of DMS, due to the lack of discursive constraints that are typical of formal discourse.

In sum, some studies have looked into the gendered differences in casual conversation concerning the selection of words, phrases, or DMs (Matei, 2011; Subon, 2013; Vanda \& Péter, 2011). The preferences of interlocutors of different genders to implement specific
DMs in specific social settings, such as university or dormitory, have not received sufficient attention in EFL settings (Yang, 2011). The current study sets out to specifically investigate the DMs applied by male students in dormitories; this random choice of men is a starting point for a future comparative study once results of an upcoming study on women's casual conversations in dormitories is carried out.

\section{Methods}

This study set out to investigate the existence of discourse markers (DMs) and the main topics of conversation that occur mostly in casual conversations among male students in dormitories, and to provide material developers and designers as well as teachers with a significant collection of DMs, often overlooked in academic sources and contexts. Furthermore, the opinion of learners towards teachers' attention to DMs is also investigated.

\section{Participants}

The participants in this study were 50 male Persian native-speaking students, ranging in age from 21 to 28 years. They comprised $28 \mathrm{BA}$ and $22 \mathrm{MA}$ students, randomly selected from Brothers Dormitories No. 3 and No. 4 of the University of Zabol. It should be mentioned that the majority of them were EFL students; however some of them were engaged in other fields of study. Table 2 below presents the specifications of the participants in the study.

Table 2

Specifications of participants

\begin{tabular}{|c|c|c|c|c|c|}
\hline Room & $\begin{array}{l}\text { Field of } \\
\text { Study }\end{array}$ & Gender & Age & $\begin{array}{l}\text { Educa- } \\
\text { tion }\end{array}$ & $\begin{array}{c}\text { No. of } \\
\text { Participants } \\
\text { in each } \\
\text { conversation }\end{array}$ \\
\hline 1 & English & Male & $21-24$ & BA & $3-6$ \\
\hline 2 & Engineering & Male & $22-26$ & BA & 5 \\
\hline 3 & $\begin{array}{l}\text { Humanities+ } \\
\text { English }\end{array}$ & Male & $23-25$ & BA & $2-6$ \\
\hline 4 & English & Male & $22-25$ & BA & $3-5$ \\
\hline 5 & $\begin{array}{l}\text { Engineering+ } \\
\text { Sciences }\end{array}$ & Male & $22-25$ & BA & $4-6$ \\
\hline 6 & Humanities & Male & $26-28$ & MA & 4 \\
\hline 7 & $\begin{array}{l}\text { Humanities+ } \\
\text { Engineering }\end{array}$ & Male & $25-28$ & MA & $2-4$ \\
\hline 8 & $\begin{array}{l}\text { S c i e nce s + } \\
\text { Engineering }\end{array}$ & Male & $26-27$ & MA & 4 \\
\hline 9 & $\begin{array}{l}\text { Humanities+ } \\
\text { Sciences }\end{array}$ & Male & $27-28$ & MA & $3-5$ \\
\hline 10 & $\begin{array}{l}\text { Engineering+ } \\
\text { English }\end{array}$ & Male & $25-28$ & MA & $2-5$ \\
\hline
\end{tabular}


The sample of students was selected from among those who had studied EFL in the University of Zabol and those who had studied English for more than 4 years in secondary school, high school, and for about one, two, or more years in the universities.

\section{Data Collection and Analysis}

The data for this study were gathered during the second semester of the 1994-95 academic year in the University of Zabol. A compact Philips GoGear Mix MP3 player and 4 mobile phones were used to record the naturally occurring, casual conversations among the participants. The recording of the conversations was carried out by one of the researchers or by an individual from each room. Over all, the authors recorded 6 hours and 3 minutes of casual conversations among male students in different contexts as summarized in Table 3 below.

Table 3

The locations of the casual conversations

\begin{tabular}{|c|c|c|c|}
\hline Location/State & $\begin{array}{l}\text { Time } \\
(\min )\end{array}$ & Location/State & $\begin{array}{l}\text { Time } \\
(\mathrm{min})\end{array}$ \\
\hline $\begin{array}{l}\text { Doing homework/ } \\
\text { Projects }\end{array}$ & 38 & $\begin{array}{l}\text { Discussions/ Talks } \\
\text { before sleeping }\end{array}$ & 31 \\
\hline Cooking & 35 & $\begin{array}{l}\text { While helping } \\
\text { each other on daily } \\
\text { lessons }\end{array}$ & 18 \\
\hline Washing dishes & 25 & $\begin{array}{l}\text { Before going } \\
\text { outside/ university }\end{array}$ & 15 \\
\hline Cleaning the room & 27 & Street ${ }^{1^{\prime \prime}}$ & 7 \\
\hline Serving tea & 23 & Shopping" & 19 \\
\hline While chatting & 10 & Playing & 14 \\
\hline $\begin{array}{l}\text { During lunch or } \\
\text { dinner }\end{array}$ & 15 & Universities Salon & 23 \\
\hline $\begin{array}{l}\text { Watching TV/Video } \\
\text { on PC }\end{array}$ & 18 & $\begin{array}{l}\text { When just coming } \\
\text { from outside/ } \\
\text { university }\end{array}$ & 12 \\
\hline
\end{tabular}

Watching Football 33

Matches

Note. The words like street and shopping mentioned in Table 3 also show the locations in which the conversations among the same participants occurred.

The data collection in this study took 3 months. The researchers selected 5 rooms from BA dormitory (room number 203, 204, 205, 208, and 215) and 5 rooms from MA dormitory (rooms number 406, 408, 412, 413, and 414). At the beginning of the study, the researcher gave participants some brief information about the aim as well as the significance of the study, and told them that their identity would be kept confidential. The recorded conversations were subsequently transcribed. It is worth noting, that Sacks, Schegloff, and Jefferson's (1974) transcription system was implemented in transcribing the collected data. In total, 3600 words were transcribed for this study. This number is not the total number of words uttered by the participants: during conversations, there were lots of interruptions or simultaneous overlapping conversations which, not being the focus of the study, were ignored. A previous study on cross-gender differences in using language and DMs (in contexts albeit different from the context of the current study) revealed that a corpus of more than 2000 words is sufficient. The researchers thus transcribed 3600 words and, following their transcription, analyzed the data using both quantitative and qualitative measures.

Furthermore, a semi- structured interview (its validity was confirmed by two experts in Applied Linguistics) was conducted to find out whether Iranian EFL teachers paid sufficient attention to DMs in English classrooms. Therefore, researchers selected 15 DMs that mostly occurred in the learners' oral production, based on the results of question number 2 (Table 5 and Table 6 below), arranged a meeting with 20 participants, all of them were EFL students who studied English translation or teaching, and then the following questions were explored:

- Did learners know the English equivalent of DMs?

- Did they believe that EFL teachers pay sufficient attention to DMs?

Their answers were coded and a list of all codes was prepared. Afterward, the frequency of codes was calculated and these results were analyzed.

\section{Results and Discussion}

The major aim of the current study was to identify and count specific DMs that were implemented by male Persian-speaking students who lived in the universities' dormitories. Meanwhile, the main topics of conversation among participants were identified. Furthermore, learners' attitudes towards teachers' attention to DMs were investigated.

The first research question deals with the topics discussed in the dormitories. The results are depicted in Table 4.

Table 4

Topics of casual conversation among BA-BA and $M A-M A$ male speakers

\begin{tabular}{lll}
\hline \multicolumn{1}{c}{ Topics } & $\mathrm{F}^{*}$ & Ratio \\
\hline Homework/Projects & 9 & $18 \%$ \\
\hline Job/Unemployment & 7 & $14 \%$ \\
\hline Sports & 6 & $12 \%$ \\
\hline University Professors & 5 & $10 \%$ \\
\hline Money/ Economic Problems/ expenses & 5 & $10 \%$ \\
\hline
\end{tabular}




\begin{tabular}{lll}
\hline Telegram, WhatsApp, Instagram, ... & 4 & $8 \%$ \\
\hline Politics & 3 & $6 \%$ \\
\hline $\begin{array}{l}\text { Cooking Foods, Washing the dishes/cleaning } \\
\text { the room, making tea }\end{array}$ & 3 & $6 \%$ \\
\hline University/ Dormitory shortcoming & 2 & $4 \%$ \\
\hline $\begin{array}{l}\text { Air Pollution, Transportation/ } \\
\text { Universities' Buses }\end{array}$ & Traffic/ & 1 \\
\hline Education/ Girl-Friend/ Marriage & 1 & $2 \%$ \\
\hline Vocation/ Travelling & 1 & $2 \%$ \\
\hline Shopping/ Home and family & 1 & $2 \%$ \\
\hline
\end{tabular}

*F= Frequency

Table 4 includes topics that Iranian male speakers frequently talk about in casual conversations. The frequency and ratio of each topic are presented through $\mathrm{F}$ and $\mathrm{P}$ (percent) respectively. As demonstrated in Table 4, dormitory students most often talk about topics like homework/projects $(\mathrm{F}=9, \mathrm{P}=18)$, job/ unemployment $(\mathrm{F}=7, \mathrm{P}=14)$, sports $(\mathrm{F}=6, \mathrm{P}=12)$, and university professors $(\mathrm{F}=5, \mathrm{P}=10)$ respectively, and less frequently about topics like shopping/ home and family and vocation/ travelling $(\mathrm{F}=1, \mathrm{P}=2)$.

These findings are not in harmony with the Kramer's results (1974) who found that unlike women's tendency to talk about sociocultural aspects of life, books, food and, drink, men tend to talk about household expenses, taxes, and politics. One plausible reason for the divergence in results is that the participants of this study are young, educated, university students who spend most of their time studying and doing different projects/ homework. Likewise, Haas (1979) mentions that issues related to financial benefits, sports, time, and quantity received more attention in men's interactions. The reason for this gendered difference in topics may be the fact that men and women have different roles, status, and duties in daily life (Akhter, 2014). Moreover, the sample of this study is comprised exclusively of university students who spend a lot of their time on academic matters, which may lead them to select such topics.

The second research question investigates the DMs that participants implement in casual conversation. The results are presented in Table 5 below.

Table 5

The frequency and percentage of occurrence of DMs in casual conversation

\begin{tabular}{|c|c|c|c|}
\hline Persian DMs & $\begin{array}{l}\text { English } \\
\text { Equivalent }\end{array}$ & $\mathrm{F}^{*}$ & Ratio (\%) \\
\hline |-هو /-و / -رو / -رم / -نم & and/ too & 46 & $17 / 22$ \\
\hline باره /ادقيق / / اره بابا / & $\begin{array}{l}\text { yeas/ yeah/ } \\
\text { uhhm- okay then/ } \\
\text { exactly }\end{array}$ & 35 & $13 / 10$ \\
\hline
\end{tabular}

\begin{tabular}{|c|c|c|c|}
\hline /ابدا/ / نه بابا / خير/نتج & $\begin{array}{l}\text { no/ not/ no way/ } \\
\text { never }\end{array}$ & 34 & $12 / 73$ \\
\hline ديكه /ديخه دبكه & $\begin{array}{l}\text { for any or no } \\
\text { reason/ the } \\
\text { repetition of the } \\
\text { previous word }\end{array}$ & 23 & $8 / 61$ \\
\hline - هرجه جى / جرا - جى & $\begin{array}{l}\text { why- what for- } \\
\text { whatever }\end{array}$ & 19 & $7 / 11$ \\
\hline خب / خو / اها /اهوم & well/good/ aha & 17 & $6 / 36$ \\
\hline مبدونى /ميفهى & $\begin{array}{l}\text { you know/ } \\
\text { understand }\end{array}$ & 16 & $5 / 99$ \\
\hline 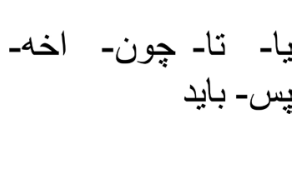 & $\begin{array}{l}\text { or- until/ in order } \\
\text { to- because- } \\
\text { well/ because- so/ } \\
\text { then- must/ } \\
\text { should }\end{array}$ & 16 & $5 / 99$ \\
\hline بالاخره / ولى- اخه- & $\begin{array}{l}\text { but- well/ } \\
\text { because- at last/ } \\
\text { tell you at brief }\end{array}$ & 15 & $5 / 61$ \\
\hline كنه /تا- اكه / تنازه- & $\begin{array}{l}\text { that, for / to- if- } \\
\text { even }\end{array}$ & 14 & $5 / 24$ \\
\hline 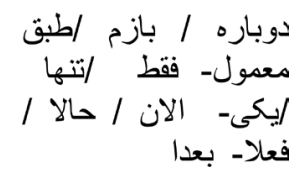 & $\begin{array}{l}\text { again/ as usual - } \\
\text { just/ only- now/ } \\
\text { the time being } \\
\text { / temporary - } \\
\text { then/later }\end{array}$ & 9 & $3 / 37$ \\
\hline عجب- ||||| اي بابا & $\begin{array}{l}\text { Well/ exclamation } \\
\text { word- vow- } \\
\text { exclamation } \\
\text { word/ oh God }\end{array}$ & 8 & $2 / 99$ \\
\hline لغيا / نكا كن / ببين & look/ see/watch & 5 & $1 / 87$ \\
\hline جذى / راستى / و واقعا & $\begin{array}{l}\text { really/ honestly/ } \\
\text { your are kidding }\end{array}$ & 4 & $1 / 49$ \\
\hline
\end{tabular}

Table 5 represents 70 DMs that were frequently reoccurred in the casual conversation among BA and MA learners in the dormitory. As Table 5 reveals, the DM "and/ too" ( $\mathrm{F}=46, \mathrm{P}=17.22)$, "yeas/ yeah/ uhhmok" ( $\mathrm{F}=35, \mathrm{P}=13.10)$, and "no" ( $\mathrm{F}=34, \mathrm{P}=12.73)$ are the most frequent ones, respectively Likewise, "really"

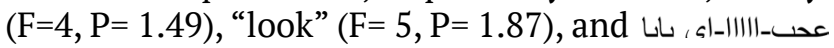
with no exact English equivalent are the least frequent ones. The high occurrence of the DM "and/ too" in casual conversation among male speakers can be justified in the light of the fact that in Persian we have more than 6 DMs as:

arich resemble such conjunctions. Moreover, due to the significant of head phrase in utterances they were added to the main nouns or verbs. Another implication of such DMs is their utilization instead of pronouns.

The interesting finding of this study was related to the special casual terms that were used by learners 
and the other participants in casual interactions. A summary of these terms and phrases is presented in Table 6.

Table 6

Specific terms (Words/ Phrases) used by the participants

\begin{tabular}{|c|c|c|}
\hline Words/ Phrases & Standard form & English Equivalent \\
\hline مماتد & خسته هستم & Tired out \\
\hline خلافى داشتن/ سازمان & اضافه وزن داشتن & Being obese \\
\hline قيفو & قيافش ر اببين & Look at him/her \\
\hline تو سايت كسى رفتن & نو نخ كسى رفتن & $\begin{array}{l}\text { Thinking about/ } \\
\text { watching someone }\end{array}$ \\
\hline آزير باش & حو است جمع باتثد & Be careful/watch out \\
\hline آزيز باش & حو است جمع باشد & $\begin{array}{l}\text { Be nobody's fool/she/ } \\
\text { he is very clever }\end{array}$ \\
\hline
\end{tabular}

The in-depth analysis of the communication among the BA-BA and MA-MA learners demonstrated the fact that male speakers in the dormitory context preferred to use more imperative forms, more challenging, and less polite terms like please or would you mind, although they were university students and considered members of an academic community. Besides, it was seen again and again that they tended to implement specific terms or raise their intonation to control their co-communicator's behavior or express their personality. These findings can be connected to the Wood (2011) claim that males prefer to use more directive utterances than females.

The third research question explores the participants' attitudes toward teachers' degree of emphasis on English DMs and provides learners with their equivalents. The results of the semi-structured interview are presented in Table 7 below.

Table 7

Learners attitudes towards teachers' degree of emphasis on DMs

\begin{tabular}{ll}
\hline \multicolumn{1}{c}{ Attitudes } & $\begin{array}{c}\text { Ratio } \\
(\%)\end{array}$ \\
\hline $\begin{array}{l}\text { Focusing just on the DMs that were presented in the } \\
\text { course books }\end{array}$ & 90 \\
\hline Providing the literal meaning of the DMs & 80 \\
\hline Enough opportunities to practice DMs orally & 24 \\
\hline $\begin{array}{l}\text { Relatedness of introduced DMs to the oral fluency and } \\
\text { accuracy }\end{array}$ & 32 \\
\hline $\begin{array}{l}\text { Teacher-centered classrooms are appropriate context } \\
\text { for teaching DMs }\end{array}$ & 52 \\
\hline $\begin{array}{l}\text { Task-based or content-based activities have more } \\
\text { fruitful results }\end{array}$ & 56 \\
\hline $\begin{array}{l}\text { Teachers explicit and implicit explanations concerning } \\
\text { the roles and functions of DMs are more effective }\end{array}$ & 44 \\
\hline
\end{tabular}

\begin{tabular}{ll}
\hline $\begin{array}{l}\text { Short clips and videos lead to the more effective } \\
\text { implementations of DMS }\end{array}$ & 75 \\
\hline Knowing the English equivalent of casual terms & 11 \\
\hline Working on terms used in casual conversation & 15 \\
\hline
\end{tabular}

Before discussing the results of the semistructured interview, it is important that the ratio of each question be taken into account separately. For example, concerning the first statement, 90 percent of learners believed that EFL teachers just focused on DMs that were introduced in the predetermined course books. However, 10 percent noted that their teachers provided them with lots of opportunities to practice various DMs in different social settings (through role play or task completion).

80 percent of participants mentioned that teachers provided them with the English literal equivalents of DMs. However, 76 percent agreed that they did not gain enough opportunities to use DMs orally in the classrooms. Likewise, 68 percent of participants pointed out that the introduced DMs in the course books were more common in written, not oral, discourse which consequently boosted their written production not their speaking fluency and accuracy. Besides, 48 percent claimed that the current teachercentered classrooms were not suitable for teaching DMs. 56 percent noted that providing natural settings in which they can see or practice the real implication of DMs were more effective and fruitful. Likewise, 44 percent considered teacher explanations about the roles and functions of DMs more fruitful. However, 75 percent believed that viewing short clips and videos displaying the target language in peoples' daily lives and casual conversations were more beneficial.

The interesting finding of this study was the fact that 85 percent of the learners believed that instructors did not consider teaching casual terms and phrases necessary. Additionally, below 15 percent had sufficient knowledge of such words, at least they knew their English equivalents. The results of a rather similar study that was conducted by Yang (2011) confirmed these findings, claiming that EFL countries' pedagogical settings did not consider teaching DMs seriously. The findings of this research can be used as a source of comparison for future studies on gender difference by investigating applied DMs in the casual conversations of female students in dormitories.

\section{Conclusion}

While additional studies are needed, the results extracted from the qualitative and quantitative analysis of this preliminary study presents three key findings. First, more than 70 DMs occurred in casual conversations among male Persian-speaking students 
living in the university of Zabol's dormitories in the 1994-95 academic year. Second, the study identifies the recurrent topics of these casual conversations. Third, the results of the semi-structural interview indicate that EFL teachers did not put much emphasis on DMs in casual conversation from the learner's point of view. Most of the learners knew the literal meanings of the DMs used, but they didn't know how to implement these in the target language. They complained about the lack of opportunities to use them orally, which hindered the development of their speaking fluency, accuracy, and complexity.

It is a known fact that having appropriate knowledge and ability concerning the implementation of DMs leads to more spontaneous oral and written outputs (Crystal, 1988) as well as the production of coherent and well-formed utterances (Fuller, 2003). The results of the current study could help raise teachers', material developers', and curriculum designers' awareness about the importance of DMs in EFL pedagogy. Some techniques such as providing explicit and implicit information, bringing samples of natural usage of DMs in the forms of short CDs or video clips, or taskbased activities like role play, opinion exchange, or problem solving could be of great help in improving the speaking ability of foreign language learners. The present study was limited by two significant factors: the restricted number of participants and the fact that all participants were men. Expanding the study by involving a larger sample from both sexes and including speakers with different EFL proficiency levels would lead to more fruitful results.

\section{References}

Akhter, I. (2014). Differences in language use by male and female students in tertiary academia in Dhaka city (Unpublished MA dissertation). BRAC University, Dhaka, Bangladesh.

Alami, M., Sabbah, M., \& Iranmanesh, M. (2012). Gender and discourse difference: An investigation of discourse markers in Persian male-female casual conversation. Archives Des Sciences, 65(7), 204-223.

Amel-Zendedel, A., \& Ebrahimi, S. (2013). Gender differences in language use: An analysis of simin daneshvar's savushun. European Scientific Journal, 9(2), 181-189.

Attaran, A., \& Morady Moghaddam, M. (2013). Speech content analysis of male and female L2 teachers in Iranian EFL context. International Journal of Research Studies in Education, 2(2), 53-60.

Boulis, C., \& Ostendrof, M. (2005). A quantitative analysis of lexical differences between genders in telephone conversation (pp. 435-442). Proceedings of the 43rd Annual Meeting on Association for
Computational Linguistics, Association for Computational Linguistics, Morristown, NJ.

Brinton, L. (1996). Pragmatic markers in English: Grammaticalization and discourse functions. Berlin, Germany: Mouton de Gruyter.

Broadbridge, J. (2003). An investigation into differences between women's and men's speech (Unpublished MA dissertation). University of Birmingham, Birmingham, UK.

Cinardo, J. (2011). Male and female differences in communicating conflict (Unpublished MA dissertation). Coastal Carolina University, Carolina, CA.

Croucher, S. M. (2004). Like, you know, what I'm saying: A study of discourse marker frequency in extemporaneous and impromptu speaking. National Forensic Journal, 22(2), 38-47.

Crystal, D. (1988). Another look at, well, you know. English Today, 13, 47-59.

Downing, A. (2006). The English pragmatic marker surely and its functional counterparts in Spanish. In A. Karin \& S. Vandenbergen (Eds.), Pragmatic Markers in Contrast (pp. 39-58). Oxford, UK: Elsevier.

Eggins, S., \& Slade, D. (2005). Analysing casual conversation. London, UK: Equinox Publishers.

Fuller, J. M. (2003). The influence of speaker on discourse marker use. Journal of Pragmatics, 35, 2345.

Fung, L. (2011). Discourse markers in the ESL classroom: A survey of teachers' attitudes. Asian EFL Journal, 13, 199-248.

Fung, L., \& Carter, R. (2007). Discourse markers and spoken English: Native and learner use in pedagogic settings. Applied Linguistics, 28, 410-439.

Haas, A. (1979). The acquisition of genderlect. In J. Orasnu, M. Slater \& L. Adler (Eds.), Language, sex, and gender: Does la différence make a difference? (pp. 101-113). New York, NY: Annuals of the New York Academy of Sciences.

Halliday, M., Hasan, R. (1976). Cohesion in English. London, UK: Longman.

Hansen, M. B. M. (1997). Alors and donc in spoken French: A reanalysis. Journal of Pragmatics, 28(2), 153-187.

Howden, J. C. (1994). Competitive and collaborative communicative style: American men and women, American men and Japanese men. Intercultural Communication Studies, 1, 49-58

Johnstone, B. (2008). Discourse analysis. Oxford, UK: Blackwell Publishing.

Khaghaninejad, M. S., \& Bahrani, M. (2016). Focusing on the relationship between speaking fluency/ accuracy of EFL learners of both genders and their listening comprehension. Mediterranean Journal of Social Sciences MCSER Publishing, 7(3), 444-450.

Kramer, C. (1974). Women's speech: Separate but 
unequal? Quarterly Journal of Speech, 60(1), 14-24.

Kumaravadivelu, B. (2006). Understanding language teaching: From method to post method. New Jersey, NJ: Erlbaum.

Lakoff, R. (1975). Language and woman's place. Language in Society, 2(1), 45-80.

Lazare, A. (2005). On apology. Oxford, UK: Oxford University Press.

Long, M. H. (1981). Input, interaction and second language acquisition. In $\mathrm{H}$. Winitz (Ed.), Native language and foreign language acquisition (pp. 259-275). New York, NY: Annals of the New York Academy of sciences.

Macaulay, R. (2002). You know, it depends. Journal of Pragmatics, 34, 749-767.

Macaulay, R. (2008). Discourse variation. In J. K. Chambers, P. Trudgill \& N. Schilling-Estes (Eds.), The Handbook of Language Variation and Change. Cambridge, UK: Blackwell Reference Online.

Maltz, D., \& Borker, R. (1982). A cultural approach to male-female conversation. In J. Gumperz (Ed.), Language and social identity (pp. 196-216). Cambridge, UK: Cambridge University Press.

Matei, M. (2011). The influence of age and gender on the selection of discourse markers in casual conversations. Philology and Cultural Studies, 4(53), 213-220.

Muller, S. (2005). Discourse markers in native and nonnative English discourse. Amsterdam, Netherlands: John Benjamins.

Murar, I. (2008). The functionality of discourse markers in conversational text. Annals of the University of Craiova, 1, 125-139.

Nasiri-Kakolaki, L., \& Shahrokhi, M. (2016). Gender differences in complaint strategies among Iranian upper intermediate EFL students. Studies in English Language Teaching, 4(1), 1-15.

Paltridge, B. (2012). Discourse analysis: An introduction ( $2^{\text {nd }}$ ed.). London, UK: Bloomsbury.

Piurko,E.(2015). Discourse markers: Their function and distribution in the media discourse (Unpublished MA dissertation). University of Educational Sciences, Lithuania.

Rahimi, F., \& Riasati, M. J. (2012). The effect of explicit instruction of discourse markers on the quality of oral output. International Journal of Applied Linguistics \& English Literature, 1(1), 70-81.

Redeker, G. (1991). Linguistic markers of discourse structure. Linguistics, 29(6), 1139-1172.

Renkema, J. (2004). Introduction to discourse studies. Amsterdam, Netherlands: John Benjamins Publishing Company.

Sacks, H., Schegloff, E. A., \& Jefferson, G. (1974). A simplest systematics for the organization of turntaking for conversation. Language, 50, 696-735.
Schiffrin, D. (2001). Discourse markers. In D. Schiffrin, D. Tannen \& H. E. Hamilton (Eds.), The Handbook of Discourse Analysis (pp. 54-75). Malden, MA: Blackwell.

Singh, S. (2001). A pilot study on gender differences in conversational speech on lexical richness measures. Literary and Linguistic Computing, 16(3), 251-264.

Subon, F. (2013). Gender differences in the use of linguistic forms in the speech of men and women in the Malaysian context. IOSR Journal of Humanities and Social Science, 13(3), 67-79.

Sukegawa, H. (1998). Some aspects of women's linguistic behavior in English speech form: A sociolinguistic study. St. Luke's College of Nursing Departmental Bulletin Paper, 7, 62-74.

TafarojiYeganeh, M., \& Ghoreishi, S. M. (2014). Exploring gender differences in the use of discourse markers in Iranian academic research articles. Global Journal of Guidance and Counselling, 4(1), 6-12.

Tannen, D. (1984). Conversational style: Analyzing talk among friends. Norwood, MA: Albex.

Vanda, K. H., \& Péter, F. B. (2011). Gender differences in the use of the discourse markers you know and I mean. Argumentum, Debreceni Egyetemi Kiadó, 7, $1-18$.

Vygotsky, L. S. (1978). Mind in society: The development of higher psychological processes. Cambridge, MA: Harvard University Press.

Wardhaugh, R.(2005).An introduction to sociolinguistics. Oxford, UK: Blackwell.

Watanabe, M. (2002). Fillers as indicators of discourse segment boundaries in Japanese monologues. In Speech Prosody, International Conference, UUniversity of Tokyo, Japan.

Wenjing, X. (2012). Study on gender differences in English. In Proceedings of the International Conference on Education Technology and Management Engineering (pp. 218-221). Chongqing, China: University of Science and Technology.

Wierzbicka, A. (2003). Cross-cultural pragmatics: The semantics of human interaction (2nd ed.). Berlin, Germany: Mouton de Gruyter.

Wood, J. T. (2011). Gendered lives: Communication, gender, and culture. Boston, MA: Wadsworth Cenage Learning.

Xia, X. (2013). Gender differences in using language. Theory and Practice in Language Studies, 3(8), 14851489.

$\mathrm{Xu}, \mathrm{Y}$. (2009). Gender differences in mixed-sex conversations: A study of interruptions (Unpublished MA dissertation). Kristianstad University, Sweden.

Yang, S. (2011). Investigating discourse markers in pedagogical setting: A literature review. ARECLS, 8 , 95-108. 
Yilmaz, E. (2004). A pragmatic analysis of Turkish discourse particles: Yani, işte and şey (Unpublished $\mathrm{PhD}$ thesis). Technical University, Turkey.

Yule, G. (2006). The study of language. Cambridge, UK:
Cambridge University Press.

Zarei, F. (2013). Discourse markers in English. International Research Journal of Applied and Basic Sciences, 4(1), 107-117. 